\title{
Odnos i značenje medijskog odgoja u dječjim vrtićima: pravila i medijski izazovi
}

Prethodno priopćenje__ DOI 10.22522/cmr20190148_ primljeno 4. veljače 2018.

UDK: $373.2: 316.774$

373.24

........

\section{Suzana Peran}

Hrvatsko katoličko sveučilište, Zagreb, Hrvatska.

E-adresa: suzanavp@gmail.com

\section{Anđelka Raguž}

Filozofski fakultet (doktorandica), Zagreb, Hrvatska.

E-adresa: anraguz@gmail.com

\section{Sažetak}

Rad prikazuje pristup i ulogu odgojitelja u medijskom odgoju djece. Slijedom toga, medijsko opismenjavanje djece promatramo s obzirom na sposobnost odgojitelja da se kompetentno i primjereno služe medijima, da su pritom kritični, medijski pismeni i svjesni (djelomične) odgovornosti kako pri stvaranju medijskih uradaka, tako i kao korisnici i kreatori medijskih sadržaja. Medijskim su sadržajima istodobno izložena i djeca koju odgojitelji obrazuju i odgajaju te im kroz odgojne metode i profesionalne pristupe sadržajno implementiraju teme i preporuke o korištenju medija. Medijski odgoj djece ovisi o obitelji, skrbnicima, utjecaju vršnjaka te se faktično navike o korištenju usvajaju i oblikuju i kroz programe i komunikacijske aktivnosti u dječjim vrtićima i predškolskim ustanovama. Stoga, rezultatima istraživanja provedenog metodom ankete među odgojiteljima iz dviju županija, utvrđujemo kako mediji pomažu u radu s djecom - koja ih poimaju kao alat za učenje, istodobno razvijajući digitalne kompetencije, i uče na zanimljiv način.

Ključne riječi: medijski odgoj, medijska pismenost, odgojitelji, dječji vrtići, odgovornost 


\section{Uvod}

U radu promišljamo važnost i ulogu medijskog odgoja djece od njihove najranije dobi s posebnim težištem na ulogu odgojiteljica i odgojitelja u vrtićima. Polazište za istraživanje su dosadašnja istraživanja koja govore o izloženosti djece medijima već od najranije dobi (Ilišin, Marinović-Bobinac, Radin, 2001; Ciboci, Kanižaj, Labaš, 2014; Ciboci, Labaš, 2015) - neki autori govore i o „medijskom djetinjstvu“ (Mikić, 2004) - te saznanja o važnosti medijske pismenosti roditelja, odgojitelja i nastavnika kako bi razumjeli današnju djecu i pravilno ih odgojili (Zgrabljić Rotar, 2005). Aktualnost teme ovoga rada potvrdili su i rezultati prvoga nacionalnog istraživanju o predškolskoj djeci pred malim ekranima koje su proveli Poliklinika za zaštitu djece i mladih Grada Zagreba i Hrabri telefon u vrtićima u Republici Hrvatskoj u 2016. i 2017. godini. To je istraživanje pokazalo da svaki drugi predškolac u dobi od dvije do četiri godine provodi ukupno dva ili više sata dnevno uz različite ekrane (Poliklinika za zaštitu djece i mladih Grada Zagreba, 2017). Prema istraživanju, 97,2 \% predškolske djece gleda televiziju, više od dvije trećine djece koristi mobitel i tablet, 60 \% djece se koristi računalom, a svako četvrto dijete koristi igraće konzole. Pritom 40 \% jednogodišnje djece koristi ekrane. Kako su potvrdili roditelji djece vrtićke dobi, 97 \% predškolaca zna samostalno uključiti neki elektronički uređaj, a 90 \% ih samostalno traži sadržaje koji ih u medijima zanimaju. Tek $40 \%$ roditelja je nazočno dok je dijete pred ekranom, a svaki četvrti roditelj gotovo nikada ne podučava svoje dijete o korištenju ekrana. Istodobno, 87 \% roditelja provodi više od četiri sata radnim danom s djetetom (Poliklinika za zaštitu djece i mladih Grada Zagreba, 2017). Djeca koja pohađaju vrtić u vrtićkim skupinama s odgojiteljima provode - prema Pravilniku o upisu djece $\mathrm{u}$ vrtić Grada Zagreba za 2017. godinu - 7 do 10 sati u cjelodnevnom boravku, odnosno, manji broj djece 4 do 6 sati u poludnevnom boravku. Upravo na temelju toga podatka da vrtićka djeca provedu više vremena s odgojiteljima nego s roditeljima - a znajući da djeca i o medijskim navikama uče na temelju primjera roditelja i odgojitelja (Six, Frey, Gimmler, 2013, str. 15-16; Miliša, 2011, str. 9), cilj je ovoga rada - budući da nedostaju istraživanja na tome području - istražiti medijske navike odgojiteljica i odgojitelja ${ }^{1} \mathrm{u}$ vrtićima te načine na koje koriste medijske sadržaje u svojim odgojnim skupinama. Budući da sustavni medijski odgoj započinje tek u osnovnoj školi kroz nastavu Hrvatskoga jezika (Ciboci, Kanižaj, Labaš, 2014, str. 53), kada su djeca već stekla navike kao medijski korisnici, odgoj za medije prepušten je do tada roditeljima (Sindik, 2012) i odgojiteljima u

$1 \mathrm{U}$ daljnjem tekstu: odgojitelji. 
vrtiću koji nemaju obvezu medijskog odgoja djece, nego odgajaju svojim izborom medija za rad i razgovorom o medijskim temama s djecom (Eder, Roboom, 2014, str. 503), a često ni sami nisu medijski pismeni, odnosno obrazovani za korištenje medija (Peran, Raguž, 2016, str. 381).

U radu koristimo termin medijska pismenost, koji se jednako kao i medijsko obrazovanje koristi u istraživanjima i studijama, dok se u službenim dokumentima koristi nedovoljno definiran termin medijske kulture (Kanižaj, Car, 2015, str. 26). Medijska pismenost je mogućnost pristupa medijima, njihova upoznavanja, analiziranja i kritičkog vrednovanja te sposobnost stvaranja medijskog sadržaja (Aufderheide, 1993), odnosno sposobnost kritičkog analiziranja i stvaranja medija u različitim oblicima (Hobbs, 2016).

\section{Empirijsko istraživanje}

S obzirom da odrastanje i socijalizacija djece i mladih uvelike ovisi, s jedne strane o obitelji i/ili skrbnicima te $s$ druge strane o utjecaju vršnjaka i odgojitelja u dječjim vrtićima, te da djeca svoje svakodnevne navike usvajaju i oblikuju i kroz programe i komunikacijske aktivnosti u dječjim vrtićima i predškolskim ustanovama, pretpostavka je da će se interpretacijom rezultata empirijskog istraživanja provedenog među odgojiteljima rasvijetliti njihova uloga u medijskom odgoju djece. Ciljevi su istraživanja bili utvrditi shvaćanje utjecaja medija na kreiranje stavova odgojitelja; znanja odgojitelja o pojmu i svrsi medijske pismenosti te načine korištenja medija i vrednovanje medijskih sadržaja u svakodnevnom radu s djecom. Slijedom toga, svrha empirijskog istraživanja bila je rasvijetliti ulogu odgojitelja - pripadnika generacije digitalnih useljenika (Veen, Vrakking, 2006; Palfrey, Gasser, 2008; Tapscot, 2009) - u medijskom opismenjavanju djece - pripadnika digitalne generacije, koji su istodobno i „prirodni suputnici suvremenim medijima“ (Livingstone, Bovill, 2001; Livingstone, 2002; Buckingham, Willett, 2013). Pritom smo $u$ anketnom istraživanju, među ostalim, nastojale propitati na koji način odgojitelji shvaćaju utjecaj medija na kreiranje vlastitih stavova i vrednovanje medijskih sadržaja. Za istraživanje su postavljene sljedeće hipoteze:

$H_{1}$ : Odgojitelji, kao korisnici medija u svakodnevnom životu, prihvaćaju i svoju ulogu u medijskom odgoju povjerene im predškolske djece.

$H_{2}$ : Odgojitelji na području medijskog odgoja žele podijeliti odgovornost s roditeljima. 
Temeljem toga postavljeno je pet istraživačkih pitanja:

P1: Koliko odgojiteljice i odgojitelji aktivno koriste medije u svom radu?

P2: Na koji način medijima pristupaju kao publika?

P3: Jesu li odgojiteljice i odgojitelji svjesni svoje uloge u medijskom odgoju djece?

P4: Koje propuste, odnosno, dobre primjere prepoznaju u medijskom izvještavanju?

P5: Koliko poznaju osobitosti i uzuse medijske kulture?

Nadalje, odgojiteljima smo $u$ istraživanju pristupale na tri razine kroz koje smo (radi lakše preglednosti) interpretirale i dobivene rezultate. Na prvoj smo im razini pristupale kao medijskoj publici. To je ujedno i jedina razina koju ostvaruju u vremenu izvan rada s vrtićkom djecom (s kojom svakodnevno surađuju). Isto tako, radi činjenice da su djeca i mladi u Hrvatskoj znatno izloženi medijima (DKMK, Ipsos Puls, 2015 prema Kanižaj, Car, 2015, str. 23; EU Kids Online Hrvatska, 2017), ispitanicima smo pristupale i kao korisnicima i vrednovateljima medijskog sadržaja na razini onih koji poučavaju djecu o korištenju medijskih sadržaja, o pozitivnim i negativnim učincima izloženosti medijima i kvaliteti gotovih medijskih uradaka te onima koji implementiraju medije i medijske sadržaje u radu s djecom. Posljednja razina na kojoj smo činile razdiobu odgovora ispitanika spram predmeta istraživanja bila je kombinacija prethodne dvije razine, uokvirena njihovom medijskom aktivnošću: aktivni komunikatori i korisnici, nasuprot uloge kreatora sadržaja privatno i u svakodnevnom radu s djecom.

\subsection{Metoda istraživanja}

Istraživačka metoda korištena $u$ empirijskom istraživanju je kvantitativna (pisana) anketa - ujedno najčešće korištena metoda prikupljanja podataka u društvenim znanostima (Tkalac Verčič i sur., 2010, str. 103). S obzirom na predmet istraživanja, metoda ankete pokazala se idealnom tehnikom prikupljanja informacija o mišljenju, znanju i stavovima kod većeg broja odgojitelja iz različitih dječjih vrtića u istom vremenskom razdoblju. Istraživanje je podrazumijevalo konstrukciju anketnog upitnika, provedbu istraživačke ankete među odgojiteljicama i odgojiteljima s područja Grada Zagreba i Zagrebačke županije i naposljetku analizu te interpretaciju dobivenih odgovora. Pri interpretaciji prikupljenih rezultata korištene su metode deskriptivne statistike. 
U istraživački upitnik uvrštena su pitanja otvorenog i zatvorenog tipa, koja su vrednovana Likertovom skalom, jer smo istraživanjem željele obuhvatiti pitanja čiji bi odgovori bili u vezi s ciljevima istraživanja, ali smo ujedno kroz pitanja otvorenog tipa ostavile i mogućnost za saznanja o eventualnim područjima koja nismo uključile u anketni upitnik. To znači da smo prepoznale „važno[st] ispitanicima dopustiti potpunu slobodu kako bismo dobil[e] što potpuniju sliku o svim mogućim stavovima i mišljenjima“" (Supek, 1968, str. 140) u vezi s pravilima i izazovima medijskog odgoja djece. Pred kraj upitnika postavile smo i pitanja u vezi s povjerenjem $u$ medije (smatrajući to važnim s obzirom na razumijevanje funkcioniranja medija), a s obzirom kako to nije implicitna tema istraživanja, ponudile smo dihotomne opcije odgovora $d a / n e$ i filtar opciju ne znam kako sadržajno ne bismo „opteretile“ upitnik i vrijeme za ispunjavanje.

Anketni je upitnik sadržavao 35 pitanja i ispitanicima je unaprijed bila zajamčena anonimnost prilikom davanja odgovora, a sukladno preporukama ${ }^{2}$ samih odgojitelja. Upitnik je izrađen u GoogleDoc formatu te je poslan na elektroničke adrese odgojitelja iz svih dječjih vrtića s područja Grada Zagreba i Zagrebačke županije. U ovom slučaju navodimo kako je anonimnost bila izuzetno važan faktor jer smo u ranijim razgovorima s odgojiteljima utvrdile nelagodu s obzirom na njihovu participaciju u ovakvom znanstvenom istraživanju kojim se nastoji saznati i ponešto o specifičnim odgojnim metodama i pravilima koje se provode u pojedinom vrtiću. Indikativnim stoga smatramo odgovore onih ispitanika $\mathrm{i}$ ispitanica koji su sudjelovali u istraživanju jer time predmnijevamo da je njihov „medijski angažman“ veći i da imaju izraženiju svijest o ulozi i važnosti medija u životima djece. Anketni su upitnici poslani na elektroničke adrese 250 odgojitelja i odgajatelja. Povratne informacije dobivene su od 80 ispitanika.

\subsection{Uzorak}

Anketa je provedena na prigodnom (raspoloživom) uzorku od 80 odgojitelja i odgojiteljica iz dječjih vrtića na području Grada Zagreba i Zagrebačke županije ${ }^{3}$ - ispitanici su ujedno predstavnici ciljane populacije (pojedinci) koji su dostupni u prigodi na koju se odnose rezultati istraživanja (Milas, 2009, str. 406). Riječ je o vrsti neprobabilističkog uzorka koji nije biran prema „kriteriju matematičke vjerojatnosti nego u skladu s kriterijima i pretpostavkama, očekivanjima ili znanjem istraživač[ic] $\mathrm{a}^{4}$ o populaciji na koju se rezultati

2 Nedostatak vremena tijekom radnog dana i proceduralni koraci oko dobivanja suglasnosti roditelja prilikom provedbe istraživanja u prostorijama s djecom.

3 U istraživanju je sudjelovalo $97 \%$ odgojiteljica i 3 \% odgojitelja od 24 do 64 godine života. 35 \% ispitanika ima završen diplomski sveučilišni studij, a $29 \%$ odgojitelja preddiplomski sveučilišni studij.

4 Sadržaj u uglatim zagradama je nadodan. 
generaliziraju “ (Lamza-Posavec, 2006, str. 108). Kao posljedica toga, rezultate istraživanja, koje je provedeno u studenome 2017. godine, ne možemo poopćavati, ali im pristupamo indikativno, a istraživanje smatramo dobrim polazištem za daljnja slična istraživanja.

\section{Rezultati istraživanja i rasprava}

Kako bismo utvrdile tehničke i praktične kompetencije odgojitelja djece rane i predškolske dobi u korištenju medija, nužno je bilo prvotno saznati koja je, kakva i kolika je uloga medija u životima ispitanika i neovisno o profesionalnoj ulozi odgojitelja u dječjim vrtićima. S time u vezi, na prvoj smo im razini pristupile kao medijskoj publici, čiji su nam odgovori važni pokazatelji (njihove) medijske pismenosti, koju smo provjeravale u nastavku.

\subsection{Korištenje medija u životu odgojitelja i odgojiteljica: tehničke i praktične kompetencije}

Provedeno je istraživanje, među ostalim, pokazalo kako odgojitelji medije koriste $u$ prosjeku tri sata dnevno. Jednako tako, rezultati pokazuju da svega 31 \% odgojitelja medije svakodnevno koristi radi informiranja o novostima iz zemlje i svijeta - čime djelomično odbacuju značenje primarne funkcije medija.U nešto većem broju slučajeva ( $40 \%$ ) odgojitelji medije koriste radi zabave i to osobito u slobodnom vremenu u kojem se medijima najčešće (44 \%) koriste i radi učenja i stjecanja novih znanja, koja onda dalje primjenjuju u radu s djecom, što pokazuje da je „kultura novoga učenja“ postala jedna od funkcija medija u suvremenim uvjetima (Rodek, 2011). Prilikom ispitivanja navika korištenja medija željele smo saznati postoji li razlika u vrsti medija koje koriste privatno i u radu s djecom rane i predškolske dobi. Rezultati prikazani u grafikonima 1 i 2 pokazuju da u slobodno vrijeme odgojitelji najviše koriste internet (27 \%), zatim televiziju (23 \%) i društvene mreže (19 \%). Društvene mreže koristi čak $94 \%$ ispitanika ${ }^{5}$ bez obzira na starosnu dob. Te rezultate možemo staviti u suodnos s rezultatima istraživanja koje ukazuje kako su u Hrvatskoj djeca i mladi (p)ostali „generacija Snapchata i mobilnih aplikacija“, dok su istodobno njihovi roditelji, nastavnici i odgojitelji (generacije starijih) prisutniji na Facebooku te da je ta društvena mreža izvor informiranja za više od 70 \% ispitanika (Obitelj u suvremenom medijskom okruženju, 2015). U profesionalnom radu s djecom 85 \% ih koristi medije, a nešto manje od četvrtine ispitanika (22 \%) koristi televiziju. Time se potvrdilo da je televizija primarni

$577 \%$ ispitanika imaju otvoren (aktivan) profil na Facebooku, 3 \% na Twitteru i $42 \%$ na Instagramu. 
medij koji koriste odgojitelji u vrtićima u radu s djecom. No, zanimljivo je istaknuti da 17 \% odgojitelja koristi radio, 8 \% njih navodi slikovnice i $1 \%$ postere kao medijska pomagala.

\section{Koje medije najčešće koristite?}

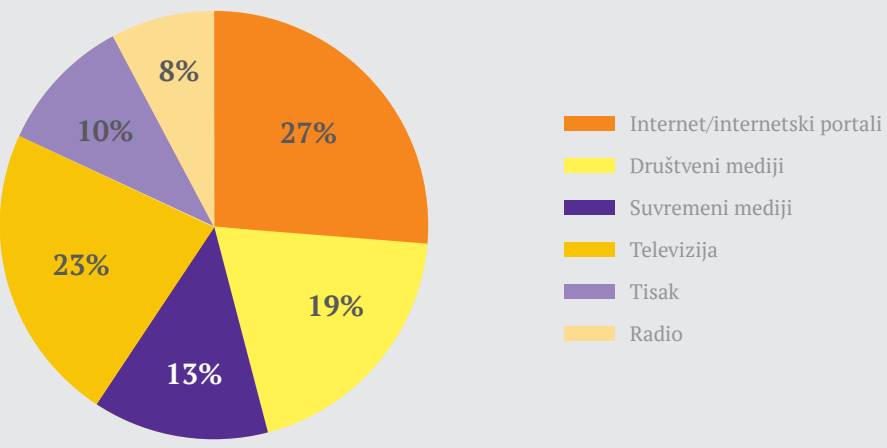

Grafikon 1. Korištenje medija u privatne svrhe $(\mathrm{N}=80)$

U istraživanju smo na razini praktičnih i tehničkih kompetencija odgojitelja željele povezati njihovo korištenje medija, prethodno obrazovanje i eventualno medijsko obrazovanje sa znanjima i angažmanom prilikom uključenosti medija $u$ aktivnosti i programe $u$ dječjim vrtićima i predškolskim ustanovama, a na taj smo način odgojiteljima pristupale kao aktivnim stvarateljima, komunikatorima i vrednovateljima medijskih sadržaja.

Koje medije najčešće koristite u radu s vrtićkom skupinom?
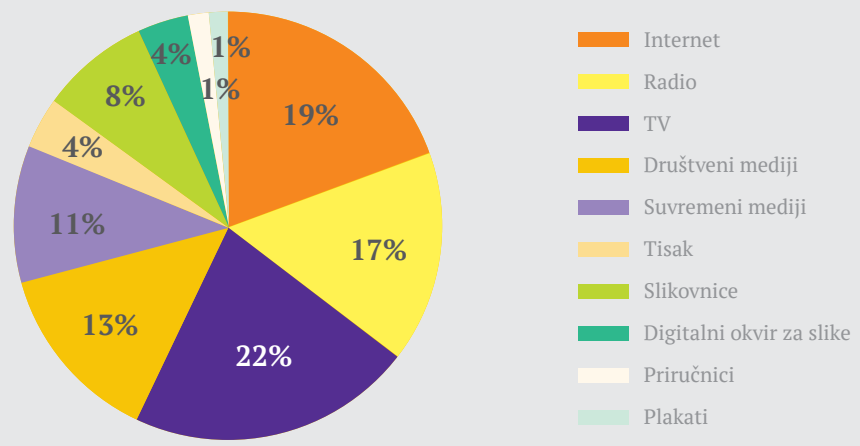

Grafikon 2. Korištenje medija u radu s djecom $(\mathrm{N}=80)$ 
Rezultati su djelomično očekivani, ali i izazovni za daljnje djelovanje na području medijske pismenosti jer svega $15 \%$ odgojitelja smatra da ih je prethodno obrazovanje pripremilo za razumijevanje medija i kritičnost prema gotovim medijskim sadržajima, čiju kvalitetu 70 \% njih ocjenjuje prema iskustvu i znanju, odnosno, 17 \% njih prema djetetovoj povratnoj reakciji. Na taj se način „oslanjaju“ na one koje sami moraju medijski odgajati. Premda su $\mathrm{s}$ jedne strane odgojitelji svjesni nedostataka u nacionalnom obrazovnom kurikulu, koji (djelomično) podrazumijeva uvrštenje nastavnih programa u kojima se uči o medijima u većoj mjeri na razini studija koji obrazuju buduće nastavnike Hrvatskoga jezika i pedagoge, s druge pak strane dvostruko veći broj ispitanika (31 \%) navodi kako zna kreirati medijsku poruku i smatraju se dobrim komunikatorima (54\%). Usporedno, neznatni postotak - od 1 $\%$ - ne poznaje korištenje tehnologije i alata $u$, kako navode, suvremenim medijima. Takvo nepostojanje sklada između obrazovnog temelja i praktične primjene znanja pokazuje da su odgojitelji prepušteni „slučajevima“, odnosno da su ponajprije svoje medijsko znanje oblikovali vlastitim angažmanom i medijskim iskustvom te iskustvom u radu s djecom, a ne podrškom cjelovite obrazovne strategije.

\section{Prethodno Vas je obrazovanje pripremilo na razumijevanje i tumačenje medijskog sadržaja}

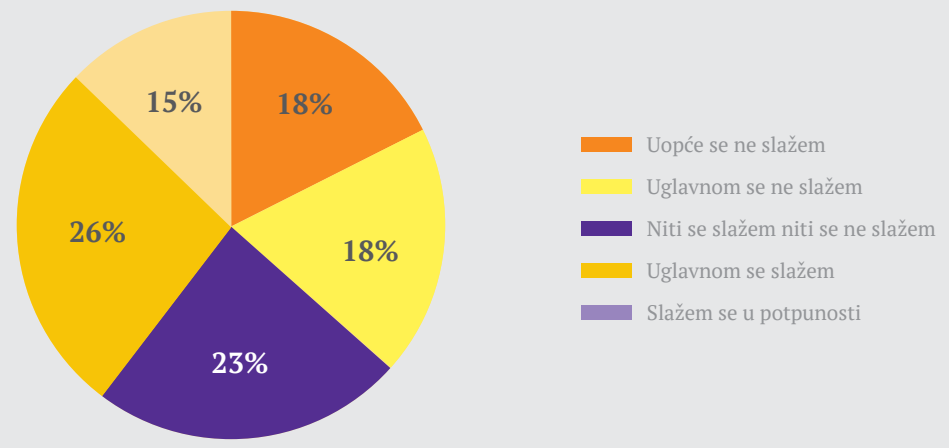

Grafikon 3. Medijsko obrazovanje odgojitelja $(\mathrm{N}=80)$

Većina odgojitelja, kao što je vidljivo u grafikonu 4 - njih 73 \%, smatra kako korisnici medija mogu utjecati na medijske sadržaje. Istodobno, njih 77 \% je izjavilo da nikada nisu reagirali na sadržaj koji je objavljen u medijima. 


\section{Može li čitatelj / gledatelj / slušatelj utjecati na medijski sadržaj?}

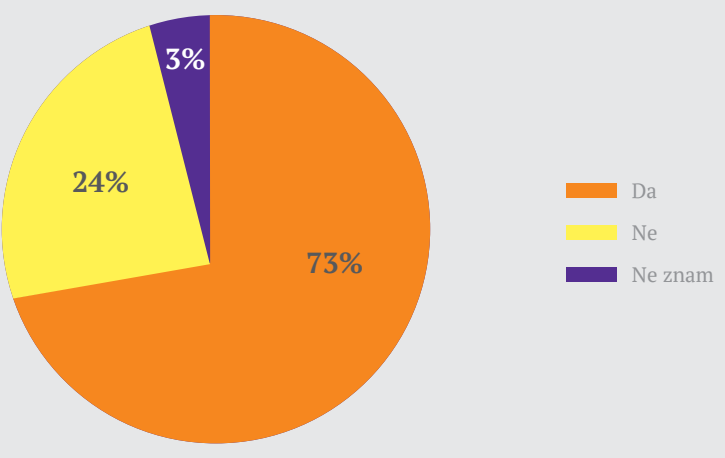

Grafikon 4. Utjecaj korisnika na medijski sadržaj $(\mathrm{N}=80)$

\subsection{Medijski odgoj djece: nužnost ili trend?}

Medijsko opismenjavanje djece, prema rezultatima istraživanja, nužnost je koja mora biti uključena i u programe i komunikacijske aktivnosti dječjih vrtića i predškolskih ustanova na razini čitave države te mora biti regulirana. Takva razmišljanja potvrđena su i ranijim istraživanjem u kojem su, primjerice, i studenti komunikologije i novinarstva - oni koji će u dogledno vrijeme stvarati medijske sadržaje, a na studijima uče kritički vrednovati medijske sadržaje - eksplicitno istaknuli važnost medijske pismenosti u obrazovnoj hijerarhiji kroz „(...) potrebu da se o medijskoj kulturi uči još i prije redovnog školovanja, i to u vrtićima, na radionicama, ali također da takvo učenje treba postati obvezno i na razini svih sveučilišnih studija“ (Peran, Raguž, 2016, str. 387). Samo 11 odgojitelja smatra da je medijska kultura u dovoljnoj mjeri trenutačno ${ }^{6}$ zastupljena u hrvatskom obrazovnom sustavu, premda njih $52 \%$ ističe više prednosti u participaciji medija u komunikaciji i odgojnim metodama u radu s djecom, nego li nedostatke. S time u vezi, otvorenim smo pitanjima nastojale od odgojitelja saznati neke od razloga koji ukazuju je li suodnos medija i djece konstantan, te na koji način, prema njihovome iskustvu, djeca mogu razvijati određene vještine i sposobnosti kroz medije. Prema ispitanicima, 
mediji imaju utjecaj na djecu što je vidljivo iz odgovora u kojima ispitanici ističu da „djeca postaju tolerantna“, „djeca uče empatiju“, „uz pomoć medija djeca upoznaju nove kulture, običaje i različitosti“, a daljnji odgovori navode da: „Koristeći se medijima, djeca razvijaju i osnažuju svoje digitalne kompetencije“, „Djeca kroz medije potiču znatiželju i razvijaju kreativnost i maštu“, „Mediji povezuju djecu s onima koji su otišli iz skupine“, „Nama mediji služe da ih educiramo na drugačiji i zanimljiv način (strani jezici, eTwinning projekti, edukativni crtani filmovi, digitalne slikovnice, tematski glazbeni uradci...).“

\section{O medijskoj kulturi bi se trebalo učiti i u dječjim vrtićima}

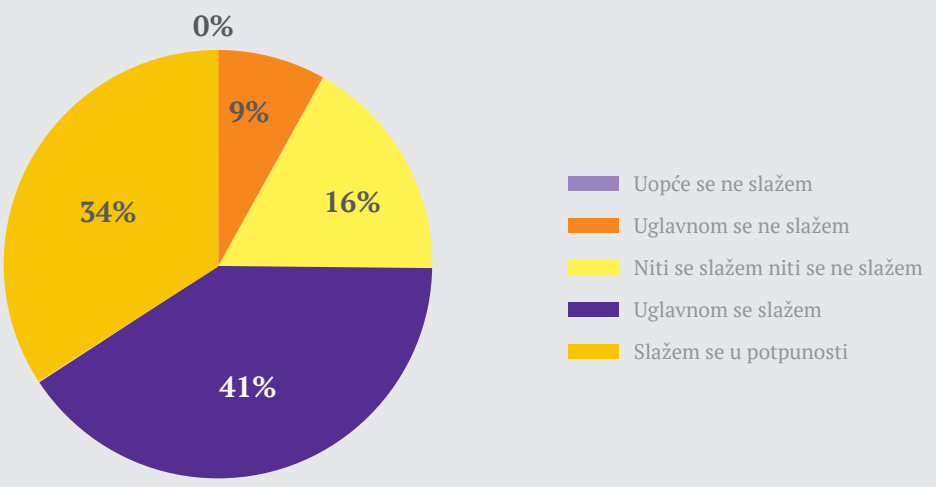

Grafikon 5. Učenje o medijskoj kulturi u dječjim vrtićima i predškolskim ustanovama $(\mathrm{N}=80)$

Rekonstrukcija do tada stečenog znanja i iskustva odgojitelja i poimanje pojma medijske pismenosti, osviještenosti o potrebi za njihovim dodatnim usavršavanjem i pristup $\mathrm{k}$ njezinoj primjeni u praksi, objašnjeni su u Tablici 1 . U istoj je vidljivo kako odgojitelji smatraju da je u medijski odgoj djece nužno uključivanje i roditelja i/ili skrbnika djece kako bi se osigurao jednak medijski tretman svim polaznicima vrtićkih skupina i predškolskih ustanova te kako medijska socijalizacija djece treba biti plod suradnje između onih koji odgajaju djecu na svim razinama njihova odrastanja. 


\begin{tabular}{|c|c|c|}
\hline & $\begin{array}{l}\text { MEDIJSKA PISMENOST: znanje i } \\
\text { poimanje }\end{array}$ & PRIJEDLOZI \\
\hline $\begin{array}{l}\text { Odgojitelji/ } \\
\text { ce i mediji } \\
\text { privatno }\end{array}$ & $\begin{array}{l}\text { Problemski orijentiran pristup; } \\
46 \% \text { poznaje pojam medijska } \\
\text { pismenost; } 29 \% \text { se smatra medijski } \\
\text { pismenim }\end{array}$ & $\begin{array}{l}\text { Medijsko obrazovanje uvrstiti u } \\
\text { programe dječjih vrtića i u studijske } \\
\text { programe na studijima koji obučavaju } \\
\text { buduće odgojitelje ( } 75 \text { \%) - rano i } \\
\text { predškolsko obrazovanje; } 49 \% \text { je } \\
\text { mišljenja kako bi se u dječjim vrtićima } \\
\text { i predškolskim ustanovama trebale } \\
\text { organizirati radionice za roditelje } \\
\text { i odgojitelje. Intenzivnija suradnja } \\
\text { roditelja i odgojitelja kroz roditeljske } \\
\text { sastanke (79\%). }\end{array}$ \\
\hline $\begin{array}{l}\text { Odgojitelji/ } \\
\text { ce i mediji } \\
\text { privatno }\end{array}$ & $\begin{array}{l}\text { Društvena rekonstrukcija znanstvenog } \\
\text { „problema“ à definira se u odnosu } \\
\text { prema društvenim problemima. } 47 \text { \% } \\
\text { mediji: sredstva za pomoć pri učenju, } \\
\text { obrazovanju i razvijanju kompetencija. } \\
\text { Četvrtina ispitanih à mediji razdvajaju } \\
\text { obitelji }\end{array}$ & $\begin{array}{l}\text { Zainteresirani za dodatno medijsko } \\
\text { usavršavanje; } \\
\text { Cjeloživotno obrazovanje }\end{array}$ \\
\hline
\end{tabular}

\subsection{Kritičke kompetencije odgojitelja}

Medijski angažman odgojitelja može se povezati i s povjerenjem u medije i s kriterijima koje uvažavaju pri odabiru i procjeni kvalitetnog sadržaja. Naše je istraživanje pokazalo da čak 51 \% odgojitelja nema jasno izražen stav o povjerenju u hrvatske medije, a medijima vjeruje svega $9 \%$ ispitanika. Ti se brojčani pokazatelji mogu usporediti sa sada već dugogodišnjim stanjem u Hrvatskoj u kojoj povjerenje građana prema medijima više čak i ne opada, već stagnira na izuzetno niskoj razini (Čuvalo, 2010).

U našoj anketi 94 \% odgojitelja smatra kako su odgovorni pri korištenju medija. Kao što je ranije prikazano, pri procjeni se u većoj mjeri oslanjanju na vlastitu intuiciju i iskustvo u odgojiteljskom radu, a njih 17 \% i temeljem djetetove povratne reakcije. Kao opasne i neprimjerene sadržaje za djecu 37 \% odgojitelja smatra stereotipne i nasilne medijski posredovane sadržaje, a $28 \%$ njih ukazuje i na opasnosti u promidžbenim porukama koje su usmjerene na djecu. Osim toga, odgojitelji upozoravaju da djeca kroz medije uče neprimjerene izraze za njihovu dob, privikavaju se na nestandardni govor, gube vezu sa 
stvarnošću oponašajući različite likove, te postaju emocionalno ravnodušna. Ipak, kao što je prikazano u grafikonu 5 , među odgojiteljima u većoj mjeri prevladava mišljenje da mediji pozitivno utječu na djecu kroz edukativne sadržaje kojima uče i razvijaju komunikacijske vještine, a 40 \% smatra da mediji pomažu u učenju.

\section{Koji su po Vašem mišljenju primjeri dobrog / kvalitetnog utjecaja medija na djecu?}

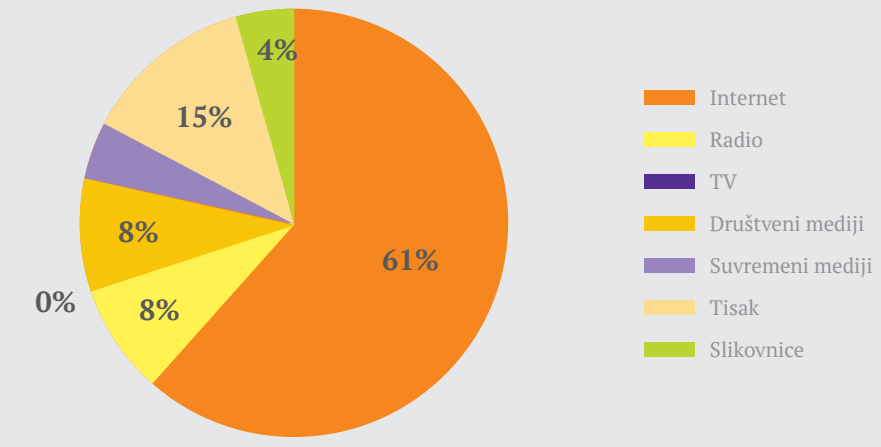

Grafikon 6. Utjecaj medijskog sadržaja na djecu $(\mathrm{N}=80)$

\subsection{Odgovornost u procesu medijskoga odgoja djece vrtićke i predškolske dobi}

Ovim smo istraživanjem analizirali i jesu li odgojitelji svjesni medijskog utjecaja na vlastite stavove, vrijednosti i odluke te postoji li s time u vezi recipročna veza u pogledu prihvaćanja vlastite odgovornosti u procesu medijskoga odgoja djece. Slijedom ranije iznesenih podataka o tome kako odgojitelji procjenjuju važnost medija u životima djece - koja usporedno s medijima razvijaju svoju kreativnost, odnosno teško im je zamislivo odrastanje djece bez suživota s medijima - indikativno je da je omjer odgojitelja koji su svjesni medijskih utjecaja na vlastite stavove i onih koji to nisu uokviren malim postotnim razmakom - 45 \% odgojitelja svjesno je medijskih utjecaja u svojim životima za razliku od $55 \%$ onih koji ga negiraju. 


\section{Odgojitelji i roditelji / skrbnici trebaju surađivati u medijskom odgoju djece}

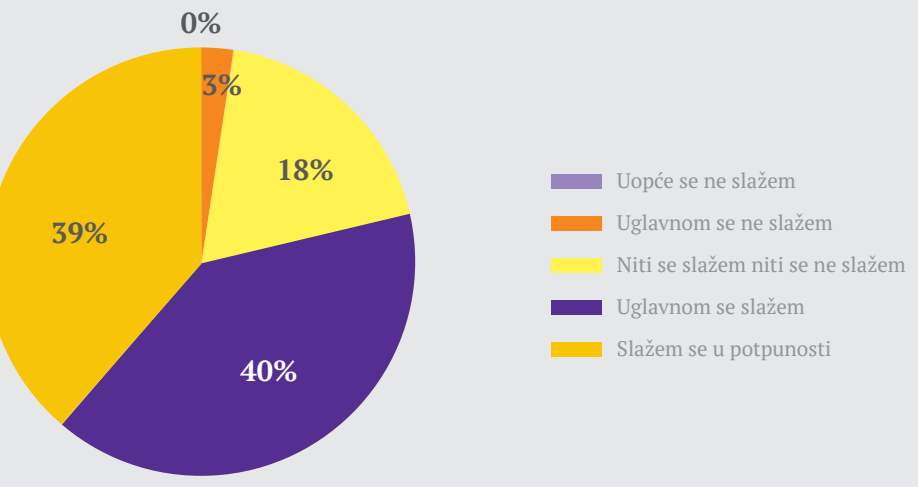

Grafikon 7. Odgovornost roditelja/skrbnika i odgojitelja u medijskom odgoju djece (N = 80)

Kao što je vidljivo u grafikonu 7, odgovornost u medijskom opismenjavanju djece i u procesu učenja djece u virtualnoj interakciji s medijima i razvijanje kritičkih sposobnosti pri vrednovanju medijskih sadržaja te stvaranje medijskih uradaka, prema mišljenju odgojitelja je podijeljena i nikako se ne bi smjela ograničiti isključivo na jednu razinu. Podijeljena odgovornost između roditelja/skrbnika djece i njihovih predškolskih odgojitelja za $79 \%$ ispitanika je razumljiva sama po sebi, dok su prijedlozi za poboljšanje uvjeta usmjereni na radionice pod stručnim vodstvom te češće roditeljske sastanke na kojima bi se roditelje/ skrbnike (stručno) usmjeravalo. U odgovoru o ulozi medija u obitelji, 39 \% ispitanika smatra da mediji u obitelji imaju informativnu, edukativnu i kulturnu ulogu, 20 \% ističe da mediji utječu negativno na obitelj, odnosno razdvajaju obitelj, a 7 \% da su mediji „dadilja“u obitelji.

\section{Zaključak}

Istraživanjem su potvrđene polazne hipoteze da odgojitelji, kao korisnici medija $u$ svakodnevnom životu, prihvaćaju i svoju ulogu u medijskom odgoju povjerene im predškolske djece i da na tom području žele podijeliti odgovornost s roditeljima. Upravo iz vlastita iskustva s medijima te iskustva rada s djecom, odgojitelji prepoznaju pozitivne utjecaje medija na djecu kao što su informiranje, edukativni sadržaji, upoznavanje različitih skupina u društvu, zabava, ali ukazuju i na negativne, to jest nasilne sadržaje i stereotipe koji su kroz medije posredovani djeci. Vlastito korištenje medija, kreiranje medijskih sadržaja većinom na društvenim mrežama ( 94 \% ispitanika), te kritičnost prema medijskim sadržajima opravdava i iskaz 29 \% ispitanika da se smatraju medijski pismenima premda kroz obrazovanje nisu slušali kolegije iz medijske pismenosti. 
Na temelju dobivenih rezultata istraživanja mišljenja smo da je, kako to iz kritičnosti prema vlastitome znanju predlažu i odgojitelji, izuzetno važno uvesti obrazovanje za medije $u$ studije koji školuju buduće odgojitelje. Polazeći od našega, ali i drugih istraživanja odnosa predškolske djece i medija, te svjesni prožetosti svakodnevnog života djece i obitelji medijima, smatramo da odgoj za medije treba uvesti u sve dijelove obrazovnog sustava - od vrtića pa sve do sveučilišta. Posebno važnim smatramo medijski opismenjavati već vrtićku djecu jer su ona najranjivija skupina medijskih korisnika, a medije koriste već od najranije dobi, no ne razlikuju realnost od svijeta mašte te su ciljana skupina različitih oglašivača koji im se obraćaju kroz promidžbene poruke koje prate igrice i ostale medijske sadržaje namijenjene djeci (Six, Gimmler, 2007, str. 20-21). Upravo vrtićke skupine u kojima se kroz igru uči i provodi socijalizacija, čine se kao pogodno mjesto i za nestrukturirano, spontano učenje o medijima, kroz igru i razgovor - kada odgojitelji primijete da djeca oponašaju nekog medijskog junaka, nose odjeću s likovima iz crtića itd. (Six, Gimmler, 2007, str. 26-27). Jednako tako na području medijskog obrazovanja djece može se kroz roditeljske sastanke i savjetovanja uspostaviti suradnja roditelja i odgojitelja u razumijevanju medija i postavljanju pravila za korištenje medija. Mediji, naime, kako je pokazalo i naše istraživanje, povezuju obiteljsku i vrtićku svakodnevicu djece jer se isti mediji koriste i u skupinama i u dječjem slobodnom vremenu (Neuss, 2013, str. 37).

Odgoj za medije povezan je i s odgojem za demokraciju kako bi se ohrabrilo djecu, učenike i studente da postanu informirani, odgovorni i medijski pismeni članovi društva (Hobbs, 1998). Medijski odgoj smatramo važnim i kao odgoj protiv manipulacije, protiv širenja lažnih vijesti i mržnje i stereotipa (Kellner, Share, 2009, str. 292), što su u svojim odgovorima prepoznali i odgojitelji. Upravo je zato važno za taj odgoj obrazovati odgojitelje i nastavnike. Zaključno smatramo da se i odgojiteljima i roditeljima, na kojima je teret medijskog odgoja predškolske djece, a da sami većinom nisu medijski obrazovani, treba pomoći u tome odgoju. To se može postići suradnjom komunikoloških/novinarskih studija sa studijima za obrazovanje budućih odgojitelja, ali i kroz različite radionice kojima bi stručnjaci za medijsku pismenost roditelje i odgojitelje u vrtićkim skupinama uputili u načine vrednovanja medijskih sadržaja i njihovog kvalitetnog korištenja u svakodnevici predškolske djece. Držimo da bi ovo istraživanje bilo korisno ponoviti među odgojiteljima i odgojiteljicama koji nisu sudjelovali u ovom istraživanju te ga proširiti i uključiti i odgojitelje iz ostalih hrvatskih županija kao i napraviti usporedbu s rezultatima istraživanja provedenima među roditeljima/skrbnicima djece kako bi se stvorilo polazište za kvalitetno medijsko opismenjavanje predškolaca koji su već uvelike izloženi utjecajima različitih ekrana. 


\section{Popis literature}

- Aufderheide, P. (1993). Media Literacy. A report of the national leadership conference on media literacy. Aspen: CO, Aspen Institute.

- Buckingham, D., Willett, R. (2013). Digital Generations: Children, Young People and New Media. Abingdon, New York: Routledge.

- Ciboci, L., Kanižaj, I., Labaš, D. (2014). Media Education from the Perspective of Parents of Preschool Children: Challenges and Trends in Free Time Media Use. Medijska istraživanja, 20 (2), 53-69.

- Ciboci,L.,Labaš,D.(2015).Utjecajmedijanaigrudjecepredškolskedobi.363-388.U:Smajić,D.,Majdenić,V.(ur.),Dijeteijezikdanas.Dijeteimediji. Osijek: Sveučilište J. J. Strossmayera u Osijeku, Fakultet za odgojne i obrazovne znanosti.

- Čuvalo, A. (2010). Osobine medijskih publika i povjerenje u medije. Medijske studije, 1 (1-2), 40-54.

- Eder, S., Roboom, S. (2014). Klicken, Knipsen, Tricksen .... Medienerziehung im Kindergarten, 503-516. U: Tillmann, A., Fleischer, S., Hugger, K. (ur.), Handbuch Kinder und Medien. Digitale Kultur und Kommunikation. Wiesbaden: Springer VS.

- EU Kids Online Hrvatska (2017).Dostupno na: http://www.lse.ac.uk/media@lse/research/EUKidsOnline/WebsitesInNationalLanguage/ Croatia.aspx/. Preuzeto 11. siječnja 2017.

- Hobbs, R. (1998). Building Citizenship Skills through Media Literacy Education, 62-63. U: Salvador, M., Sias, P. M. (ur.), The Public Voice in a Democracy at Risk. Westport: Greenwood Publishing Group.

- Hobbs, R. (2016). Historical Roots of Media Literacy, 9-37.U: Hobbs, R. (ur.), Exploring the Roots of Digital and Media Literacy through Personal Narrative. Philadelphia: Temple University Press.

- Ilišin, V., Marinović Bobinac, A., Radin, F. (2001). Djeca i mediji: uloga medija u svakodnevnom životu djece. Zagreb: DZZOMM i IDIZ.

- Kanižaj, I., Car, V. (2015). Hrvatska: Nove prilike za sustavan pristup medijskoj pismenosti, 19-38. U: Car, V., Turčilo, L., Matović, M. (ur.), Medijska pismenost - preduvjet za odgovorne medije. Zbornik radova s 5. regionalne znanstvene konferencije Vjerodostojnost medija. Sarajevo: Fakultet političkih nauka Univerziteta u Sarajevu.

- Kellner, D., Share, J. (2009). Critical media education and radical democracy, 281-294. U: Apple, M. W., Au, W., Gardin, L. A. (ur.), The Routledge International Handbook for Critical Education. London: Routledge.

- Lamza Posavec, V. (2006). Metode istraživanja u novinarstvu. Zagreb: Fakultet političkih znanosti.

- Livingstone, S., Bovill, M. (2001). Children and Their Changing Media Environment. Mahwah. New York: Lawrence Erlbaum.

- Livingstone, S. (2002). Young People New Media. London: Sage.

- Mikić, K. (2004). Mediji i roditelji.Zapis-bilten hrvatskog filmskog saveza. Dostupno na: http://www.hfs.hr/hfs/zapis_clanak_detail. asp?sif $=483$. Preuzeto 3. siječnja 2018.

- Milas, G. (2009). Istraživačke metode u psihologiji i drugim društvenim znanostima. Jastrebarsko: Naklada Slap.

- Miliša, Z. (2011). Obitelj na kušnji, Glas Koncila, 30, 9.

- Palfrey, J., Glasser, U. (2008). Born Digital: understanding the first generations of digital natives. New York: Basic Books.

- Neuss, N. (2013). Medienkompetenz in der fruehen Kindheit, 34-46. U: Hoffmann, D., Hoffmann, B., Hugger, K-U. i dr. Medienkompetenzfoerderung fuer Kinder und Jugendliche. Berlin: GMK.

- Peran, S., Raguž, A. (2016). Medijska pismenost - obrazovanje studenata i svijest o vlastitoj odgovornosti. Nova prisutnost, 14 (3), 379-393.

- Poliklinika za zaštitu djece i mladih Grada Zagreba (2017). Prvo nacionalno istraživanje o predškolskoj djeci pred malim ekranima. Dostupno na: http://www.poliklinika-djeca.hr/aktualno/novosti/prvo-nacionalno-istrazivanje-o-predskolskoj-djeci-pred-malimekranima/. Preuzeto 10. siječnja 2018.

- Rodek, S. (2011). Novi mediji i nova kultura učenja. Napredak: časopis za pedagogijsku teoriju i praksu, 152 (1), 9-28.

- Sindik, J. (2012). Kako roditelji percipiraju utjecaj medija na predškolsku djecu? Medijska istraživanja, 18 (1), 5-33.

- Six, U., Gimmler, R. (2007). Die Foerderung von Medienkompetenz im Kindergarten. Duesseldorf: VISTAS.

- Six, U., Frey, C., Gimmler, R. (2013). Medienerziehung im Kindergarten. Theoretische Grundlagen und empirische Befunde. Opladen: VS Verlag für Sozialwissenschaften.

- Tapscott, D. (2009). Grown Up Digital. How the Net Generation is Changing Your World. New York: McGraw Hill.

- Tkalac Verčič, A., Sinčić Ćorić, D., Pološko Vokić, N. (2010). Priručnik za metodologiju istraživačkog rada. Kako osmisliti, provesti $i$ opisati znanstveno i stručno istraživanje. Zagreb: M.E.P.

- Veen, W., Vrakking, B. (2006). Homo Zappiens: Growing up in a digital age. London: Network Continuum.

- Zgrabljić Rotar, N. (2005). Medijska pismenost i civilno društvo. Sarajevo: MediaCentar. 


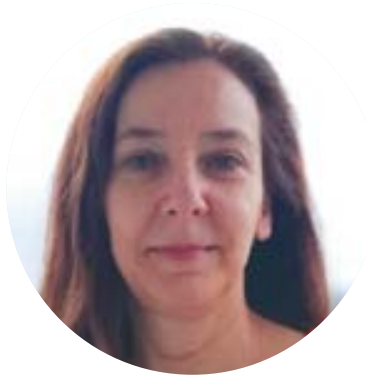

\section{Suzana Peran}

Poslijedoktorandica na Odjelu

za komunikologiju Hrvatskoga katoličkog sveučilišta.

Magistrirala je na temu odnosa Katoličke crkve i Europske unije te je doktorirala na temu odnosa obitelji i medija. Predavačica je na Studiju komunikologije na Hrvatskim studijima, na katedri Pastoralne teologije Katoličkoga bogoslovnog fakulteta te na studiju Protestantske teologije Sveučilišta u Zagrebu. Bila je glavna urednica Informativne katoličke agencije. Autorica je više zanstvenih i stručnih članaka, predavačica na novinarskim i komunikološkim simpozijima te voditeljica novinarskih tečajeva. Posebno se bavi odnosom Crkve i medija, obitelji i medija, djece i medija te odgojem za medijsku pismenost. Predsjednica je Hrvatskoga društva katoličkih novinara i članica Društva za komunikacijsku i medijsku kulturu.

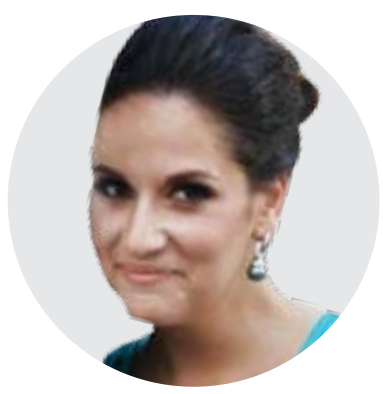

Anđelka Raguž

Doktorandica na poslijediplomskom studiju Informacijskih i komunikacijskih znanosti Filozofskoga fakulteta u Zagrebu. 2016. godine je obranila doktorsku temu: Uloga suvremenih medija $u$ životu hrvatske obitelji. Suradnica je na multidisciplinarnom znanstvenom istraživanju Obitelj u suvremenom medijskom okruženju. Izvodi nastavu i asistentica je na kolegijima preddiplomskog i diplomskog Studija komunikologije na Hrvatskim studijima. Znanstveni interesi su joj medijska pismenost, medijski odgoj, uloga medija $\mathrm{u}$ obitelji te analiza medijskog sadržaja. Sudjelovala je na domaćim i međunarodnim znanstvenim simpozijima i konferencijama te objavljuje znanstvene radove iz društvenog i humanističkog područja. 